\title{
THE DEBRIS CONTENT OF SURGING GLACIERS IN SVALBARD AND ICELAND
}

\author{
By Chalmers M. Clapperton \\ (Department of Geography, University of Aberdeen, St Mary's, High Street, Old Aberdeen, \\ $\mathrm{AB} 9{ }_{2} \mathrm{UF}$, Scotland)
}

\begin{abstract}
In Svalbard and Iceland there appears to be much more debris entrained in glaciers that surge than in those which do not. Conditions particularly favourable for the basal incorporation of debris develop as a consequence of the high flow velocities attained by a surge. These are increased cavitation in the lee of obstacles and an increased supply of basal melt water resulting from frictional heat and from the trigger zone. Layers of regelation ice incorporating debris can thus develop to a much greater vertical and horizontal extent than in non-surging glaciers. Excessive shearing, and the distortion of foliation structures in the terminal zone of compressive flow, enhance the vertical development of the debris-rich regelation layers. Glaciers that surge over outwash and/or fjord-bottom sediments become particularly rich in debris.

RÉsumé. Sur la teneur en matériaux des glaciers en crue en Svalbard et en Islande. En Svalbard et en Islande, il est apparu qu'il y avait beaucoup plus de matériaux entraînés dans les glaciers en crue rapide que dans ceux qui ne le sont pas. Des conditions particulièrement favorables pour l'incorporation de matériaux à la base du glacier naissent comme une conséquence des hautes vitesses d'écoulements atteintes par la crue. Il y a accroissement de la cavitation à l'aval des obstacles et un apport supplémentaire d'eau de fusion à la base par la chaleur de frottement et en provenance de la zone de foirage. Il peut, dès lors, se développer des niveaux de glace de regel incorporant les matériaux à une échelle beaucoup plus grande, dans les directions verticales et horizontales que dans les glaciers qui ne sont pas en crue rapide. Le cisaillement excessif et la distorsion des structures de foliation dans la zone terminale de l'écoulement compressif empêche le développement en hauteur des niveaux de regel riches en matériaux. Les glaciers qui avancent rapidement par dessus des sédiments fluviaux ou de fond de fjord deviennent particulièrement riches en matériaux.

Zusammenfassung. Ubber den Schuttgehalt ausbrechender Gletscher in Svalbard und Island. In Svalbard und Island scheint der Schuttgehalt in ausbrechenden Gletschern weit höher zu sein als in anderen. Besonders günstige Bedingungen für die Aufnahme von Schutt am Untergrund entwickeln sich als Folge der hohen Fliessgeschwindigkeiten während eines Ausbruches. Sie bestehen aus der Cavitation im Lee von Hindernissen und aus dem erhöhten Zufluss von Schmelzwasser infolge der Reibungswärme am Untergrund und aus der Auslösezone. Schichten mit schutterfülltem Regelationseis können sich so in weit grösserer Vertikal- und Horizontalerstreckung bilden als bei nicht ausbrechenden Gletschern. Übermässige Scherung und die Verbiegung von Bänderstrukturen in der Endzone kompressiven Fliessens verstärken die vertikale Ausbildung schuttreicher Regelationsschichten. Gletscher, die über Schwemmland und/oder Sedimente auf Fjord-Böden ausbrechen, werden besonders schuttreich.
\end{abstract}

\section{INTRODUCTION}

Recent observations and theories on the origin, entrainment, and melt-out of subglacially derived debris at Svalbard glaciers by Boulton (1967, 1968, 1970[a], 1970[b], 1972[b]) have greatly advanced our understanding of sedimentation processes at the margins of existing glaciers and also of the likely origin of complex till sequences deposited by Pleistocene ice sheets. One of Boulton's conclusions, however, namely that many polar and sub-polar glaciers carry much more basally-derived debris than temperate glaciers prompted a stimulating exchange of conflicting views with J. T. Andrews in the pages of this fournal (Andrews, I97I, I972; Boulton, I97I, I972[a]). The main controversy centres round the fact that Andrews considered Boulton's generalization to be inapplicable in Baffin Island and that in his experience "moraines . . in temperate areas are considerably larger than those in Arctic glaciers ..." (Andrews, 1972). The present writer has recently examined subpolar glaciers in Svalbard and a temperate glacier in Iceland in the context of their surging behaviour and believes that the latter characteristic is of much greater significance to the BoultonAndrews controversy than the generalized thermal characteristics of the glaciers.

Accepting that basal melt water is fundamental for the subglacial incorporation of debris (Boulton, I970[b]), this paper first of all considers the role of basal melt water at surging glaciers before considering all of the factors that may explain the debris content of two such glaciers. 


\section{SURGING GLACIERS AND BASAL MELT WATER}

It has been apparent for a number of years that cyclic surge behaviour is common in both temperate and polar environments and to virtually all shapes and sizes of glacier (Meier and Post, 1969). There also seems to be general agreement that the high flow rates attained by most glaciers during their active surge phase are due mainly to accelerated basal slippage. In developing a general theory and model of cyclically surging glaciers Robin and Weertman (1973) assume that a surge starts when the glacier suddenly flows so easily that it must lower its basal shear stress to the value $\tau_{0}$. Advocating that the likely mechanism to achieve this state depends on the presence of water at the base of the glacier, they conclude by emphasizing the crucial role that a gradient in basal shear stress may play in causing water to accumulate under a glacier and to start it to surge by lubricating a trigger region. Based as it is on the presence of basal melt water this theory is therefore satisfactory for all wet-based (temperate) glaciers and for glaciers that are wet-based in the accumulation area but dry-based (cold) in the ablation area (i.e. subpolar glaciers). The theory implies that any glacier that is wholly dry-based and frozen to its bed cannot surge (e.g. the Meighen Ice Cap, which has a basal temperature of $-15.9^{\circ} \mathrm{C}$ at the deepest part (Paterson, 1969)).

This paper does not seek to assess the merits of the Robin-Weertman model in relation to other theories of glacier surges (e.g. Nielson, I969; Palmer, 1972), but accepts its premise that basal melt water is necessary for the surge mechanism and aims to emphasize the fundamental

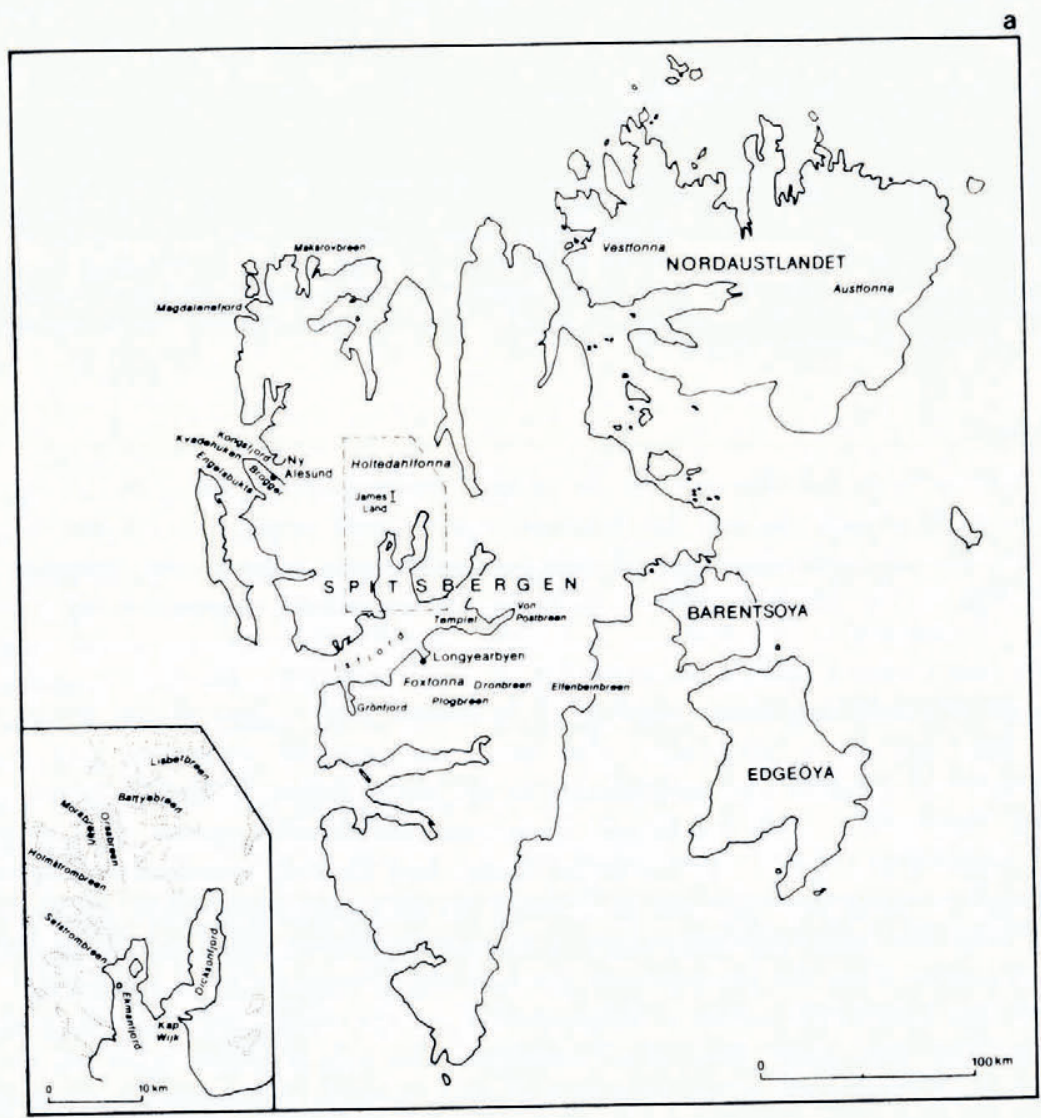

Fig. I. Map of Svalbard showing the location of glaciers and places referred to in the text. 
role of that water in the subglacial entrainment of debris by surging glaciers in Svalbard and Iceland. It is first of all necessary to briefly consider the thermal characteristics and debris content of these glaciers.

\section{Basal temperatures of Svalbard and Icelandic glaciers}

Temperature data on Svalbard glaciers are generally meagre but Schytt (1964) has shown that basal ice in the accumulation area of Vestfonna and probably also of Austfonna (Fig. I) is at the pressure melting temperature whereas in the ablation area the basal ice is cold. Liestøl (1973), however, has measured basal temperatures below the melting point all over the small and shallow plateau ice cap Foxfonna, where layers of impermeable superimposed ice may prevent the glacier from being warmed up by percolating melt water. All such glaciers should be wholly cold-based and it may be predicted that none of them will surge.

It is unlikely that any glaciers in the maritime climate of Iceland are cold and dry-based despite the presence of permafrost in the ground adjacent to some of them (for example north of Vatnajökull). This was confirmed for part of the northern edge of Vatnajökull (Fig. 2) where an ice cliff recently formed by the drainage of an ice-marginal lake between Eyjabakkajökull and Bruarjökull exposes the ends of many englacial and subglacial meltwater tubes, and it is also substantiated by the fact that the majority of melt streams issue subglacially from Icelandic glaciers. This contrasts with Svalbard glaciers where most of the melt water flows in supraglacial and marginal channels.

The available thermal data thus indicate that it should be possible for basal melt water to be present all over most Icelandic glaciers and at least at the accumulation area of large Svalbard glaciers.

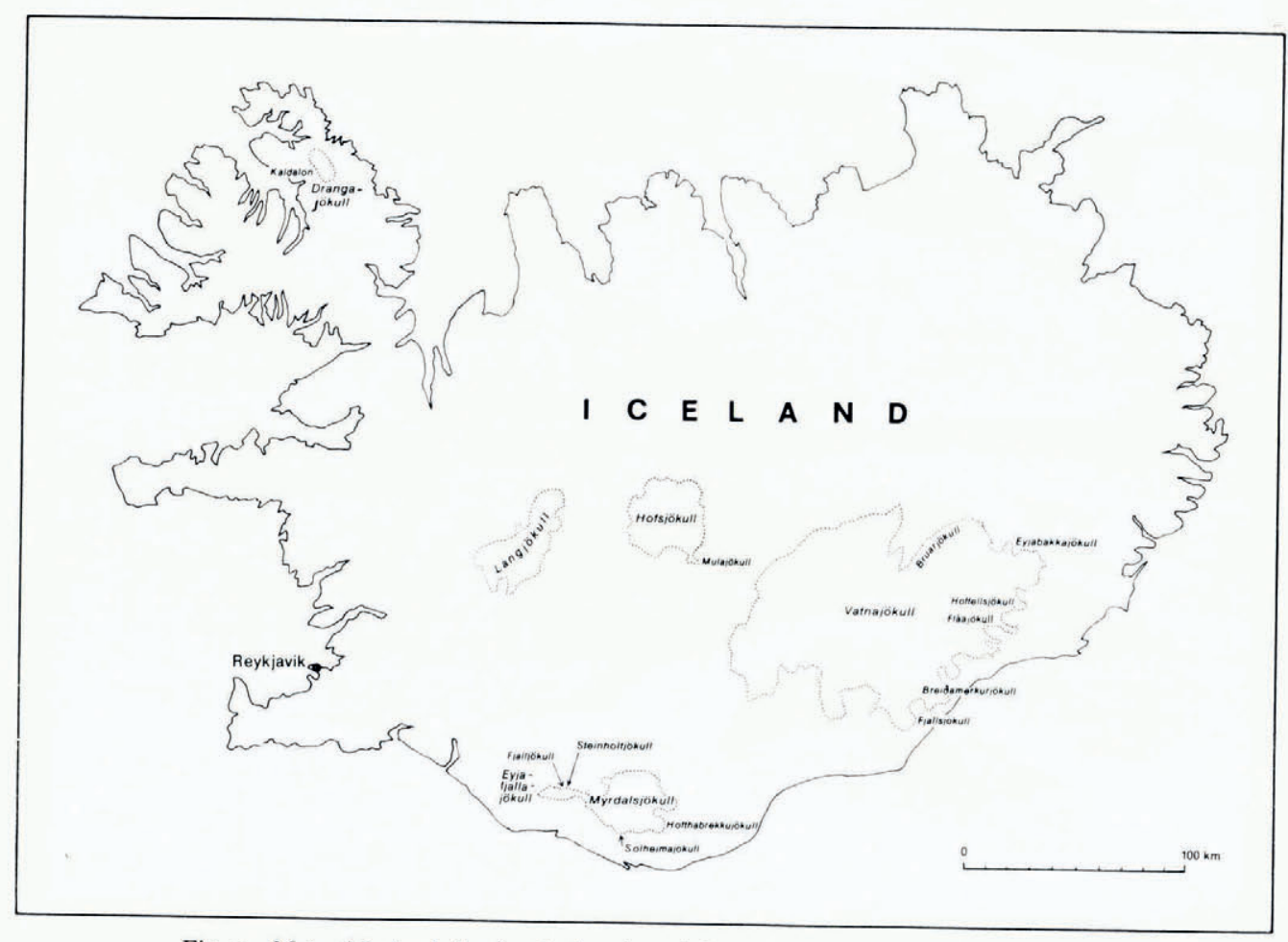

Fig. 2. Map of Iceland showing the location of glaciers and places referred to in the text. 


\section{Debris content of Svalbard glaciers}

Some Svalbard glaciers not only contain much more debris than others but also have deposited a much more extensive and complex moraine beyond their presently active margin. The contrast between such glaciers is partly a topographical one. Those bounded by extensive rock walls, such as the cirque glaciers and independent valley glaciers, receive large amounts of superficial debris through frost-shattering processes operating on the walls. Thick accumulations of this angular material have given rise to very large ice-cored moraines by insulating underlying ice from solar radiation, and these normally mark the maximum position attained by the glaciers in Neoglacial times. Short outlet glaciers from some of the smaller plateau ice caps (e.g. Foxfonna) on the other hand usually carry less debris and are fronted by smaller moraines. By far the most impressive moraine complexes and heaviest debris concentrations are associated with the larger valley glaciers. Some of this debris falls from nunataks and valley walls but as Garwood and Gregory (1898) and Boulton (1967, 1968) observed, a great deal of the material covering the glaciers and contained within the glaciers is striated, abraded and thus basally derived.

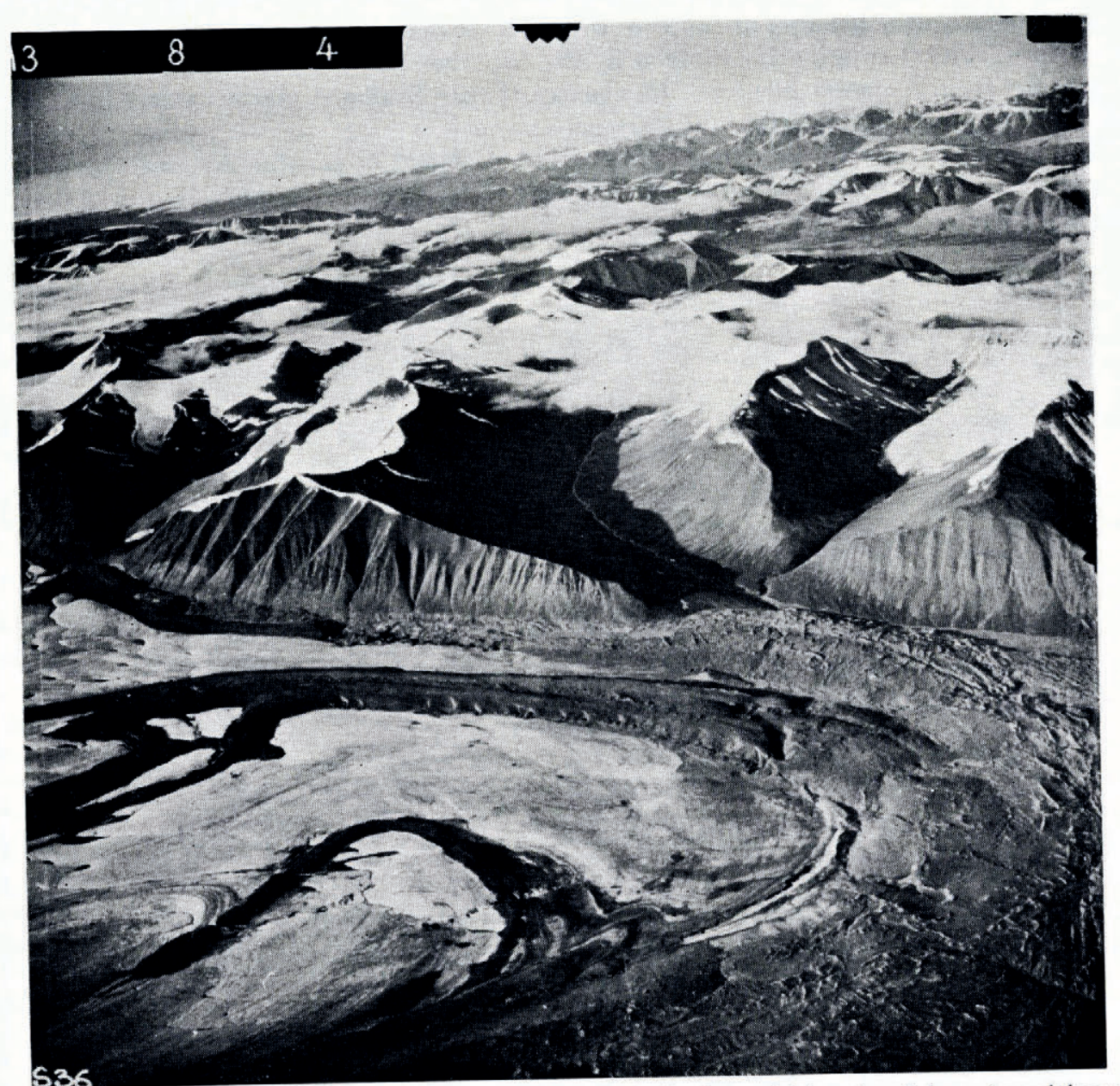

Fig. 3. The stagnant terminal zone of Holmstrombreen, Svalbard, showing loops of deformed medial moraine and the complex pattern of melt-out till ridges in the debris-rich snout region. (Photograph by Norsk Polarinstitutt.) 
Holmstrombreen at the head of Ekamfjord is a particularly fine example that is representative of this type of glacier, and for this reason some details of its debris content and structure are given below.

\section{Debris content and ice structures of Holmstrombreen}

Holmstrombreen, a valley glacier $25 \mathrm{~km}$ long and averaging $2.5 \mathrm{~km}$ in width, flows from an ill-defined catchment area linked to the large ice cap Holtedahlfonna in James I Land (Fig. I). Two large tributaries, Orsabreen and Morabreen, both $18 \mathrm{~km}$ long, drain directly from Holtedahlfonna and become confluent with each other and with Holmstrombreen only $5 \mathrm{~km}$ from the glacier terminus. It is possible that Holtedahlfonna, like Vestfonna and Austfonna in Nordaustlandet (Schytt, I969), may be at the pressure melting temperature at the base, but the ablation zone of Holmstrombreen and its tributaries appears to be cold-based because all of the melt water is confined to supraglacial and shallow-seated englacial channels. The lower $8 \mathrm{~km}$ of the glacier now appears to be stagnant and is the location of an extensive debris cover. Much of this is a formless mantle of melt-out till, generally $\mathrm{I}-\mathrm{I} .5 \mathrm{~m}$ thick. The till also forms sets of conspicuous ridges projecting $\mathrm{I}-3 \mathrm{~m}$ in height above the ice surface; some are ice-cored, others are ice-free. The most continuous ridges are those which curve parallel to the stagnant glacier snout (Fig. 3). Shorter but equally distinct till ridges intersect the curving ones, orthogonally in many places and at oblique angles in others. A few of these cross ridges are slightly sinuous in plan. Part of the debris cover of Holmstrombreen consists of a relatively thin layer of angular debris derived from deformed loops of lateral and medial moraine. A minor contribution to the debris cover is made by the melt streams transporting and redepositing debris that melts out of their channel walls and by the sediments of ephemeral lakes and ponds on the glacier surface. Probably the most conspicuous landform at Holmstrombreen is the extensive arc of Jura-like ridges of pushed fjord sediments. Thinly veneered with outwash gravel, these sands and silts are arranged as parallel anticlinal ridges, the crests of which become progressively higher closer to the stagnant glacier tongue.

Sections exposed by the main melt streams at the very snout of the glacier reveal largescale structures in the stagnant ice where thrust planes sloping upwards from the base at angles of $20-60^{\circ}$ and folded foliation structures are dominant (Fig. 4). Banded ice made up of many layers of clear ice lacking any obvious macro-crystalline structure, but containing suspended particles of fine sediment, is also commonly developed. The layers of clear ice, normally $5 \mathrm{~cm}$ thick, are usually separated by bands of almost pure debris up to $2 \mathrm{~cm}$ thick. This type of glacier ice is quite distinct from the comparatively debris-free macro-crystalline ice (crystals over $5 \mathrm{~cm}$ ) exposed farther up-glacier in the debris-free zone. The tectonically deformed, banded ice is essentially similar to that identified at Magarovbreen as regelation ice by Boulton ( $1970[\mathrm{~b}])$. Thrust features and folds in basal ice were also observed by Garwood and Gregory (1898) at Elfenbeinbreen, Dronbreen and Plogbreen, glaciers that were undergoing rapid advances (now classified as surges) at the time of their visit in 1896 .

\section{Surging glaciers in Svalbard}

There are many reports of heavily crevassed, rapidly advancing glaciers in Svalbard (Garwood and Gregory, I898; Lamplugh, I9I I; Pillewizer, I939; Glen, I94I); so much so that Liestøl (1969) concluded "surges are frequent phenomena in Spitsbergen; in fact they constitute a common form of glacier advance". In 1970 , aerial monitoring of glacier movements showed that 12 glaciers were surging, at least one of which was advancing farther than at any other time during the Neoglacial period (Liestøl, I97I). In addition to those reported to have surged, considerable numbers of Svalbard glaciers display the surface, structural, and morphological characteristics now believed to be diagnostic of glaciers that surge (Meier and Post, 1969). Features such as contorted and displaced moraine loops, truncated tributary 


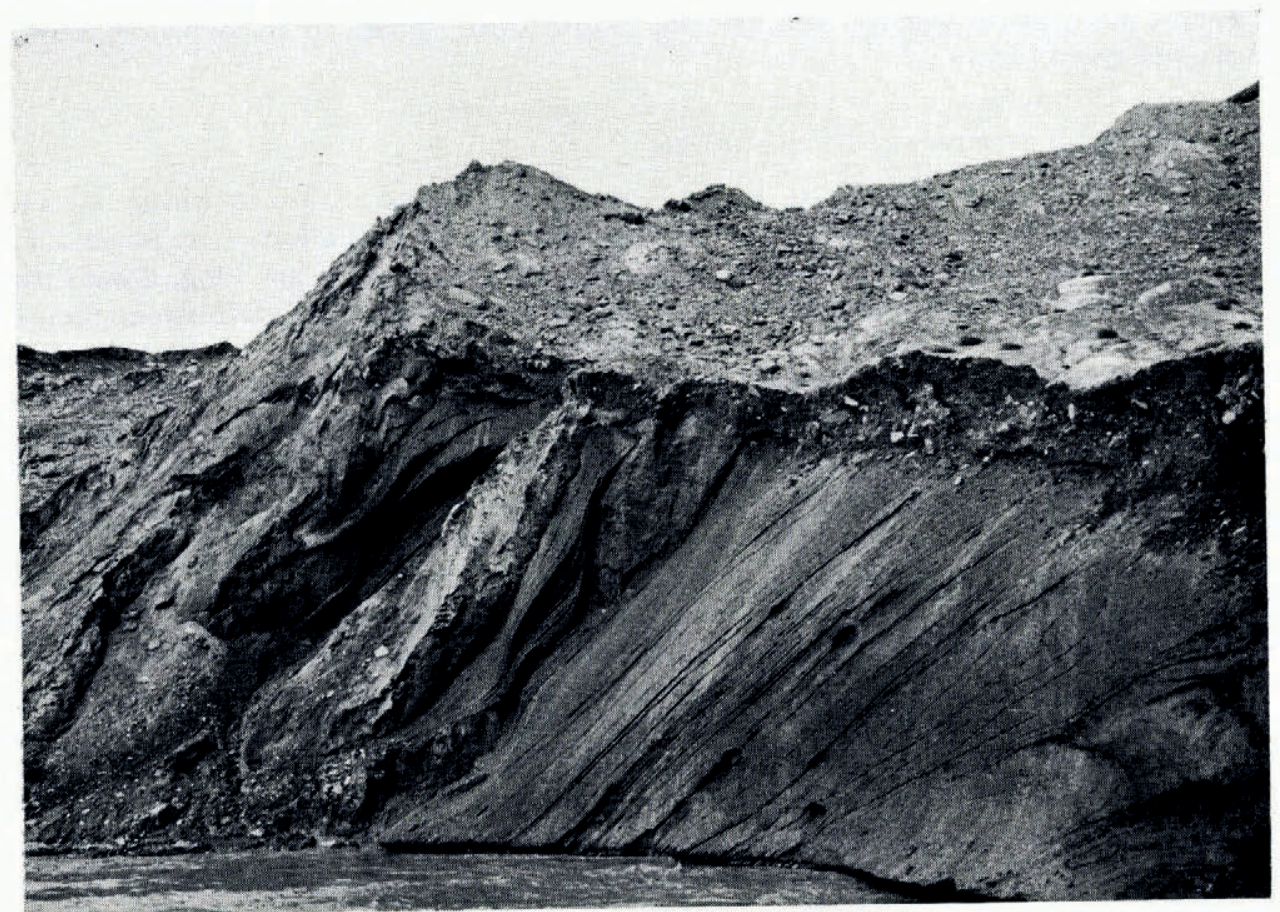

Fig. 4. Steeply inclined structures in debris-rich regelation ice exposed near the terminus of Holmstrombreen, Svalbard. The overlying layer of melt-out till is about $1.5 \mathrm{~m}$ thick.

glaciers, and extensive stagnant tongues, are typical not only of Holmstrombreen but also of the majority of other glaciers with push moraines described by Gripp (1929). Battyebreen and Lisbetbreen flowing from Holtedahlfonna a short distance east of Holmstrombreen also possess prominent moraine loops and push moraines.

In view of the close association between surging behaviour and high debris content, it seems possible that a causal relationship exists between these two characteristics of Svalbard glaciers. If so a valid generalization may be that the majority of large Svalbard glaciers surge, and in so doing develop typical thrust and foliation structures, entrain much basal debris which subsequently melts out, and, in many instances, push pre-deposited sediments into push moraines.

\section{DEBris CONTENT OF ICELANDic GLAGiers}

Icelandic glaciers periodically become covered with tephra from volcanic eruptions. Layers that fall on the accumulation area usually melt out in the ablation area some tens of years later, mostly as dirt cones but also as ice-cored ridges along foliation and thrust planes. Thus many Icelandic glaciers look dirty much of the time but since this is a special type of superficial cover it is not to be confused with the basally-derived debris under discussion.

All Icelandic glaciers now lie behind terminal moraines that mark their most advanced Neoglacial positions attained in response to climatic deterioration between the late 17 th and early 2 oth centuries. Some of the glaciers, however, have much more extensive and complex moraine topography than others and, although this is not generally well documented, specific 
examples include Fláajökull and Hoffellsjökull (Okko, I955), Bruarjökull (Thorarinsson, I964), Breiðamerkurjökull (Price, I969) and Fjallsjökull (Price, I970), all of which are outlet glaciers of Vatnajökull. Mulajökull, a southern outlet of Hofsjökull and Kaldalon, a western outlet glacier of Drangajökull, also have developed extensive moraine topography. Many other adjacent glaciers from the same ice caps have notably less extensive moraine topography. Typical examples of those observed by the present writer include Fjalljökull and Steinsholtjökull, northern outlets of Eyjafjallajökull and Solheimajökull and Hofthabrekkujökull, southern outlets of Myrdalsjökull.

Eyjabakkajökull, a northern outlet from Vatnajökull was selected for detailed field studies in 1974 because it is a surging temperate glacier with a wide variety of depositional landforms surrounding the terminus. The decision to study this glacier was made before it became known that the glacier was undergoing its second recorded surge (October 1972 until October 1973) (Thorarinsson, 1973). Observations comparative to those made at Holmstrombreen are briefly reported below.

\section{Debris content and ice structures of Eyjabakkajökull}

Eyjabakkajökull is partly an independent valley glacier draining the snow fields of a mountain complex I $400-1500 \mathrm{~m}$ high at the north-eastern edge of Vatnajökull, but as much as $50 \%$ of its nourishment probably comes from the main ice cap (Fig. 2). Three major ice streams from separate accumulation basins join to form the main glacier which is $\mathrm{I} 6 \mathrm{~km}$ long and approximately $4 \mathrm{~km}$ wide at the snout. Aerial photographs taken in 1967 show that, before the recent surge, a complex belt of partly ice-cored moraine and fluvio-glacial sediments extended in front of the glacier over an arc $3.75 \mathrm{~km}$ broad extending $7.5 \mathrm{~km}$ across the valley. These deposits terminated against arcs of very conspicuous ridges of pushed proglacial sediments. Four groups of landforms are typically developed in the moraine belt. (I) Broad ridges curving normal to the ice front and composed either wholly of till or of pushed fluvial and lacustrine sediments overlain by I-2 $\mathrm{m}$ of till (up to $25 \mathrm{~m}$ high); (2) Amorphously shaped areas of conical hummocks composed of till, much of which is still ice-cored; (3) Fluted till radially aligned to the 1967 ice front and in which individual flutes are seldom more than $\mathrm{I} \mathrm{m}$ high; many are indistinct on the ground but show up clearly on aerial photographs; (4) Narrow ridges of till aligned normally, orthogonally, and obliquely to the 1967 ice margin; mostly $2-5 \mathrm{~m}$ in height and up to $400 \mathrm{~m}$ in length, they vary from straight to slightly sinuous in plan and are normally superficial forms on ground moraine $\mathrm{I}-3 \mathrm{~m}$ thick.

Good sections exposing the structure and debris content of the glacier were present in I 974 at the ice front which still retained the precipitous cliff developed during the recent surge (Fig. 5); sections were also available along parts of the northern margin of the glacier actively being undercut by melt streams. It could be seen clearly that the lower $5 \mathrm{~km}$ of Eyjabakkajökull is composed of two different types of ice, at least around the periphery. One of these occurs at the base of the glacier and is composed of bands of clear and bubbly ice commonly separated by very thin discontinuity planes heavily charged with debris particles. The layers of clear ice are $\mathrm{I}-3 \mathrm{~cm}$ thick and generally contain suspended silt particles and particle aggregates. The bubbly layers are everywhere thicker, measuring from ${ }^{1} 5^{-} 30 \mathrm{~cm}$ in thickness at the sections available; some contain suspended debris particles but others are totally free of debris. The clear and bubbly ice totally lack any macrocrystalline structure and to the eye appear cryptocrystalline. It is possible that some of the bubbly ice originates as fallen pinnacles of surface ice incorporated into the basal layers as the glacier surged forward. The basal type of ice increases in thickness from $\mathrm{I} .5 \mathrm{~m}$ at a point $5 \mathrm{~km}$ from the ice front to $8 \mathrm{~m}$ at the snout, where sections orthogonal to the ice edge reveal layers bending sharply upwards until they are nearly vertical and sections normal to the ice edge expose highly disturbed tectonic structures such as lateral overfolding and enclosed loops of banded ice. 


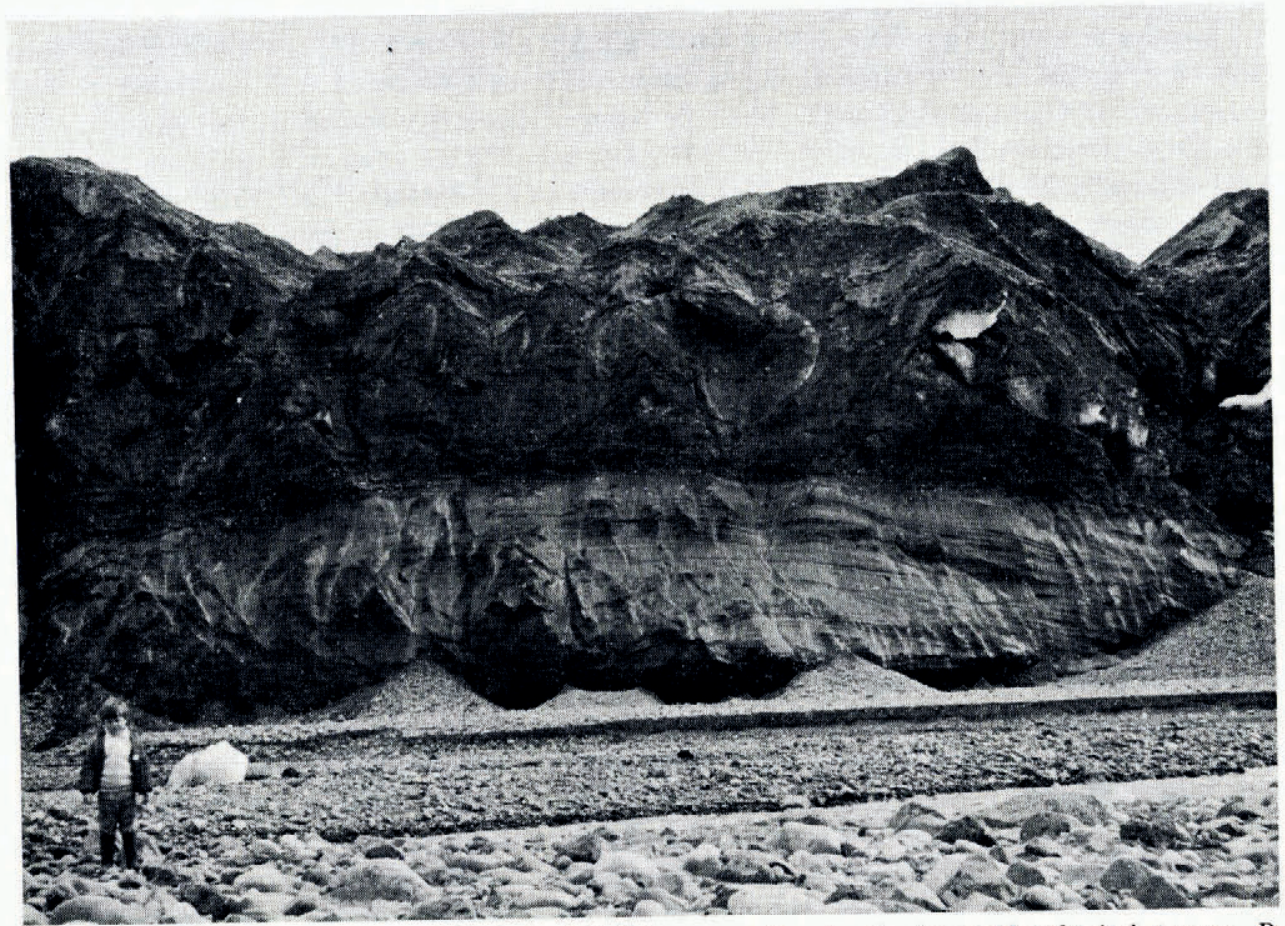

Fig. 5. Ice cliff at the snout of Eyjabakkajökull, Iceland, in July 1974, approximately nine months after its last surge. Banded debris-rich regelation ice at the base is about $10 \mathrm{~m}$ thick. The overlying crystalline ice contains very little entrained debris but appears dirty because of a superficial veneer of down-washed medial moraine.

A sharp thrust-plane discontinuity separates the basal ice from the overlying type (Fig. 5) which is characterized by large blue ice crystals $5^{-8} \mathrm{~cm}$ in size. Many foliation structures give this ice a pseudo-bedded appearance largely because of the high debris content of the foliation layers. All of the foliation planes examined proved to be composed of a $2-3 \mathrm{~cm}$ layer of regelation ice highly charged with debris. The crystalline ice is essentially free of debris except at the foliation planes. Not only are the finer debris particles concentrated here, but also the larger pebbles and boulders are welded on to the overlying ice crystals by a film of regelation ice adhering to their upper surfaces. The layers of macrocrystalline ice separated by the foliation planes are irregular in thickness, varying from $10-30 \mathrm{~cm}$, and commonly pinch out laterally.

The structure, debris content, and associated depositional landforms at Eyjabakkajökull are very similar to those at Holmstrombreen in Svalbard and to those described in Svalbard by Boulton (1970[a], [b]).

\section{Surging glaciers in Iceland}

It is now known that I I glaciers in Iceland have surged. Most of them have done so at least twice (Table I) and they are all major outlet glaciers from four of the five main ice caps. The Myrdalsjökull-Eyjafjallajökull cap is the only one with large outlet glaciers that have never been reported as surging. From the data available (Thorarinsson, 1964) it appears that at least $40 \%$ of Vatnajökull, one of the largest caps of temperate ice in the world, is affected by surge movements. Bruarjökull, one of its largest outlets, has advanced rapidly on 
five occasions during the last $35^{\circ}$ years apparently with a periodicity of $70-100$ years (Thorarinsson, I 969 ). A volume of $700 \mathrm{~km}^{3}$ of ice and firn and an ice front $45 \mathrm{~km}$ long move during these surges. Even more remarkable is the coincidence in time of surges of some of the Vatnajökull outlets (Table I), but there are insufficient data to speculate on the likely reason for such events, even although several of the surges began during the month of October. It may be concluded from the data available that surges are as common a form of glacier movement in Iceland as in Svalbard.

TABle I. Icelandic glaciers AFFected By SURGes

\begin{tabular}{|c|c|c|c|}
\hline Year & Glacier & $\begin{array}{c}\text { Distance advanced } \\
\mathrm{km}\end{array}$ & Parent ice cap \\
\hline $1972-73$ & Eyjabakkajökull & 2.0 & Vatnajökull \\
\hline 1972 & Hagafellsjökull vestri & ? & Langjökull \\
\hline 1972 & Mulajökull & ? & Hofsjökull \\
\hline I 965 & Mulajökull & ? & Hofsjökull \\
\hline $1963-64$ & Sidujökull & 0.5 & Vatnajökull \\
\hline I $963-64$ & Bruarjökull & 8.0 & Vatnajökull \\
\hline $195^{1}$ & Dyng jujöökull & 0.3 & Vatnajökull \\
\hline I 945 & Skaftarjökull & 0.6 & Vatnajökull \\
\hline I 945 & Tungnarjöklar & $>1.0$ & Vatnajökull \\
\hline I $939-42$ & Leiruf jordur & 1.5 & Drangajökull \\
\hline I $934-36$ & Kaldalon & 0.75 & Drangajökull \\
\hline I934 & Sidujökull & 0.6 & Vatnajökull \\
\hline I934 & Dyng jujökull & 0.3 & Vatnajökull \\
\hline 1890 & Bruarjökull & I0.0 & Vatnajökull \\
\hline I 890 & Eyjabakkajökull & 0.6 & Vatnajökull \\
\hline 1820 & Breiðamerkurjökull & I.o & Vatnajökull \\
\hline 1810 & Bruarjökull & ? & Vatnajökull \\
\hline I 720's & Bruarjökull & $?$ & Vatnajökull \\
\hline 1625 & Bruarjökull & $?$ & Vatnajökull \\
\hline
\end{tabular}

Table based on information from Thorarinsson ( 1969$)$.

\section{ORIGIN OF DEBRIS IN SURGING GLAGIERS}

The heavy concentration of basally-derived debris in ice cliffs exposed at Holstrombreen and Eyjabakkajökull, together with accounts and photographs of other surging glaciers, suggests that a valid generalization may be made concerning the debris content of such glaciers. It is that the majority of surging glaciers, whether they are located in subpolar or temperate regimes, are much more highly charged with subglacially-derived debris than most glaciers that do not surge.

There is therefore a need to explore the possibility that a causal relationship exists between surging behaviour and high debris content. In seeking an explanation it is clearly crucial to consider the entrainment mechanism and the boundary conditions that influence its effective operation. Recent theory developed by Boulton (1972[b]) has emphasized the fundamental role of basal melt water in incorporating debris particles and adhering them to the glacier sole when regelation occurs. Field observations in Svalbard and Iceland confirm the importance of this mechanism. It follows that glaciers which are wholly dry-based will contain very little subglacially-derived debris because of the absence of basal melt water, and that at glaciers which are wholly wet-based, where there is net basal melting and a general downward movement of ice, there can be no net accretion of regelation ice (Boulton, 1972[b]). (Here, the debris-charged layer is limited to about $0.5^{-1} \mathrm{~m}$ in thickness above the glacier bed.) It is therefore possible that particular conditions favouring basal entrainment and the vertical build-up of debris develop mainly as a consequence of the surge mechanism.

The cyclic surge theory of Robin and Weertman (I973) predicts that, when a surge begins in a trigger zone through the "lubricating" effect of accumulated basal melt water, the rapid 
sliding velocity is propagated both up and down glacier. The enhanced lubricating effect seems to be precipitated at a critical threshold value of $P$, the basal water pressure, when a chain of positive feedback events is initiated. The high value of $P$ reduces friction at the glacier bed, presumably by forcing a film of water thick enough to swamp the smaller bumps along the ice-bed interface, thereby increasing the sliding velocity. This in turn raises the tensional stress in the lee of larger bumps where cavities open up, become water filled, and possibly expand until these bumps are also swamped. Basal water pressure is maintained at a high value by the added amount of water produced by increased frictional heat at the glacier bed as a result of the higher sliding velocity. This chain of events continues until a break-off threshold is reached. According to Robin and Weertman (1973) this is when the water pressure gradient has forced basal water as far up-glacier as it can and when the basal shear stress in the surging portion of the glacier is lowered to such a low value (through the horizontal extension and vertical thinning of the glacier) that fast sliding velocities are no longer possible.

The influence of these basal conditions produced by a surge on the entrainment and vertical build-up of debris may possibly be as follows, accepting that the formation of regelation ice is the main incorporation mechanism.

At the base of a non-surging temperate glacier, regelation ice develops by the refreezing of water produced by pressure melting on the up-stream side of an obstacle. Because the heat flow required to maintain the process in equilibrium can only be conducted through obstacles no larger than about $50 \mathrm{~cm}$, it follows that the thickness of the regelation layer at any one obstacle may never be much more than of the order of several centimetres. The length of a regelation layer extending from any obstacle (in a situation of net basal melting) is limited by the distance to the next obstacle of similar or larger size, where the regelation layer is destroyed by pressure melting. At the base of glaciers undergoing a surge, however, theory predicts the widespread development of cavities and that water from the collection zone (cf. Robin and Weertman, 1973) and from frictional melting may be forced into such cavities by the basal water-pressure gradient.* When general basal melt water (produced under pressure at a temperature below $0^{\circ} \mathrm{C}$ ) flows into the lower-pressure environment of the cavities, refreezing can occur on a much larger scale than with the normal pressure-melting/refreezing mechanism. Latent heat liberated during freezing does not have to be conducted through obstacles; it can be used up in melting ice to enlarge the cavity and surplus heat can be efficiently dispersed by the circulating basal melt-water system.

A limit to the formation of regelation ice in this way is imposed (I) by cavity size and (2) when the water in a cavity is at the same pressure as water entering it. But, given a situation in which cavities are developing during a surge, this mechanism is likely to be of considerable importance, and if more regelation ice is produced than is lost by net basal melting, then a vertical sequence will develop. It is also significant that in the snout zone of intense compression and shearing so typical of surging glaciers, the regelation layers and their debris content are tectonically built up into even thicker vertical sequences. When field studies provide more data on the basal conditions under surging glaciers it may become possible to quantify the effectiveness of this enhanced regelation mechanism.

There is one further consideration important to an understanding of the apparently excessive debris content of some Svalbard and Icelandic glaciers. It is that many of these glaciers have surged over the pre-deposited sediments of an outwash plain or of a fjord head and have basally incorporated considerable amounts of these materials (in addition to tectonically deforming them into push moraines along the surface of décollement provided by

* The latter is likely to be particularly high where the bed consists of relatively impermeable materials and this is exactly the situation beneath the margins of most Svalbard glaciers, where the permafrost is over $300 \mathrm{~m}$ deep, and in parts of Iceland where permafrost occurs to the edge of some outlet glaciers, such as Eyjabakkajökull, so that immediately these glaciers surge they are underlain by an impermeable base. 
the permafrost). In Svalbard, fine sands, silts and clays containing many marine shells are common constituents of the distal melt-out tills of Holmstrombreen and Battyebreen. The remarkable reticulate till ridges of Flint and Cora Øer in Ekmanfjord, deposited by Seftstrombreen after its surge across the fjord bottom in the I89o's, are littered not only with marine shell fragments but also with complete bivalves into which fine till appears to have been forced. The silt-rich tills of Eyjabakkajökull in Iceland are similarly derived from fine alluvial sediments containing peat horizons.

All of the glaciers in Svalbard described by Boulton terminate at fjords and the majority of them have probably surged. Those studied by Andrews in Baffin Island appear not to be of the surging type. Thus the controversy over the debris content of sub-polar and temperate glaciers may be more adequately resolved if attention is directed to whether they are surging or non-surging glaciers in the first instance.

\section{AcKNowledgements}

Field work in Svalbard and Iceland was supported by major grants from the University of Aberdeen and the Carnegie Trust for the Universities of Scotland. Particular thanks are due to the Norsk Polarinstitutt and Rannsóknarað Ríkisins for giving permission to work in Svalbard and Iceland respectively.

I am also most grateful to G. Gudbergsson, P. Knape, R. Crofts, D. Croot, A. Gemmell, and others who helped in the field.

MS. received ${ }_{14}$ February 1975 and in revised form 10 April 1975

\section{REFERENCES}

Andrews, J. T. 1971. Englacial debris in glaciers. Fournal of Glaciology, Vol. 10, No. 6o, p. 410. [Letter.]

Andrews, J. T. 1972. Englacial debris in glaciers. Fournal of Glaciology, Vol. i 1, No. 61, p. 1 155 . [Letter.]

Boulton, G. S. 1967 . The development of a complex supraglacial moraine at the margin of Sørbreen, Ny Friesland, Vestspitsbergen. Journal of Glaciology, Vol. 6, No. 47, p. 71 7-35. Boulton, G. S. 1968. Flow tills and related deposits on some Vestspitsbergen glaciers. Journal of Glaciology,
Vol. 7, No. 51, p. $39^{1-4}$ I2.

Boulton, G. S. 1970[a]. On the deposition of subglacial and melt-out tills at the margins of certain Svalbard glaciers. Fournal of Glaciology, Vol. 9, No. 56, p. $231-45$.

Boulton, G. S. $1970[\mathrm{~b}]$. On the origin and transport of englacial debris in Svalbard glaciers. Fournal of Glaciology, Vol. 9, No. 56, p. 213-29.

Boulton, G. S. 1971. Englacial debris in glaciers: reply to the comments of Dr. J. T. Andrews. Journal of Glaciology, Vol. 10, No. 6o, p. 410-1 1. [Letter.]

Boulton, G. S. r 972 [a]. Englacial debris in glaciers: reply to the comments of Dr. J. T. Andrews. Fournal of Glaciology, Vol. 11, No. 61, p. 155-56. [Letter.] Boulton, G. S. $1972[\mathrm{~b}]$. Modern Arctic glaciers as depositional models for former ice sheets. Fournal of the
Geological Society of London, Vol. 128, Pt. 4, p. $36 \mathrm{I}-93$.

Garwood, E. J., and Gregory, J. W. 1898 . Contributions to the glacial geology of Spitsbergen. Quarterly Journal of the Geological Society of London, Vol. 54, No. 21 4 , p. 197-227.

Glen, A. R. $194 \mathrm{I}$. A sub-arctic glacier cap: the West Ice of North East Land. Geographical Journal, Vol. 98 ,
No. 2, p. $65^{-76}$.

Gripp, K. 1929. Glaciologische und geologische Ergebnisse der Hamburgischen Spitzbergen-Expedition 1927. Naturwissenschaftlichter Verein in Hamburg. Abhandlungen aus dem Gebiet der Naturwissenschaften, Bd. 22, Ht. 2-4,
p. 146-249.

Lamplugh, G. W. I9I I. On the shelly moraine of the Sefström glacier and other Spitsbergen phenomena illustrative of British glacial conditions. Proceedings of the Yorkshire Geological Society, Vol. 17, No. 3, p. 2 I6-41. Liestøl, O. I969. Glacier surges in West Spitsbergen. Canadian Journal of Earth Sciences, Vol. 6, No. 4, Pt. 2,
p. 895-97.

Liestel, O. 1971. Norway. Spitsbergen. Ice, No. 36, p. 5 .

Liestøl, O. r 973 . Norway. Spitsbergen. Ice, No. 4r, p. 9.

Meier, M. F., and Post, A. S. 1969. What are glacier surges? Canadian fournal of Earth Sciences, Vol. 6, No. 4,
Pt. 2, p. 807-17. Nielsen, L. E. I 969 . The ice-dam, powder-flow theory of glacier surges. Canadian Journal of Earth Sciences, Vol. 6 ,
No. 4, Pt. 2, p. $955-6$ r. 
Okko, V. 1955. Glacial drift in Iceland: its origin and morphology. Bulletin de la Commission Géologique de Finlande,

No. 170.
Palmer, A. C. 1972. A kinematic wave model of glacier surges. Fournal of Glaciology, Vol. i 1, No. 61, p. 65-72. Paterson, W. S. B. I 1969 . The Meighen Ice Cap, Arctic Canada: accumulation, ablation and flow. Journal of Glaciology, Vol. 8, No. 54, p. $34^{1-52}$.

Pillewizer, W. 1939. Die kartografischen und gletscherkundlichen Ergebnisse der Deutschen SpitzbergenExpedition 1938. Petermanns Geographische Mitteilungen, Ergänzungsheft Nr. $23^{8}$.

Price, R. J. 1969. Moraines, sandar, kames and eskers near Breidamerkurjökull, Iceland. Institute of British Geographers. Transactions, No. 46, p. $17-43$.

Price, R. J. r97o. Moraines at Fjallsjökull, Iceland. Arctic and Alpine Research, Vol. 2, No. I, p. $27-42$.

Robin, G. de Q., and Weertman, J. 1973. Cyclic surging of glaciers. Fournal of Glaciology, Vol. 12, No. 64, p. 3-18.

Schytt, V. 1964. Scientific results of the Swedish glaciological expedition to Nordaustlandet, Spitsbergen, 1957 and i 958 . Geografiska Annaler, Vol. 46, No. 3, p. 243-8r.

Schytt, V. I969. Some comments on glacier surges in eastern Svalbard. Canadian Journal of Earth Sciences, Vol. 6, No. 4, Pt. 2, p. 867-73.

Thorarinsson, S. 1964. Sudden advance of the Vatnajökull outlet glaciers 1930-1964. Fökull, Ár 14, p. 76-89. Thorarinsson, S. I 969 . Glacier surges in Iceland, with special reference to the surges of Brúarjökull. Canadian Journal of Earth Sciences, Vol. 6, No. 4, Pt. 2, p. 875-82.

Thorarinsson, S. 1973. Iceland. Glacier surges. Ice, No. 42, p. 3 . 